Table 1. Densimes of $A$. gambiae and $A$. funestus in Huts at Different Levels in the Pare District

\begin{tabular}{|c|c|c|c|c|c|c|c|c|c|c|c|c|c|c|c|}
\hline & \multicolumn{5}{|c|}{ Before dieldrin } & \multicolumn{10}{|c|}{ After dieldrin } \\
\hline & Jan. & April & $\begin{array}{c}1955 \\
\text { May }\end{array}$ & July & Oct. & Jan. & April & $\begin{array}{c}1956 \\
\text { May }\end{array}$ & July & Oct. & Jan. & April & $\begin{array}{c}1957 \\
\text { May }\end{array}$ & July & Oct. \\
\hline \multicolumn{16}{|c|}{ Untreated huts $2,000 \mathrm{ft}$. above valley ( $20-24$ huts) } \\
\hline A. gambiae & 0.3 & 0.6 & 0.2 & 0 & 0 & $0 \cdot 2$ & $0 \cdot 2$ & & 0 & 0 & $0 \cdot 5$ & 0 & 0 & 0 & 0 \\
\hline $\begin{array}{l}\text { A. funestus } \\
\text { Untreated hut }\end{array}$ & $\begin{array}{c}0.1 \\
\text { ft. abo }\end{array}$ & $\begin{array}{c}0 \cdot 1 \\
\text { e valley }\end{array}$ & $\begin{array}{c}1.9 \\
(5-6 \mathrm{hu}\end{array}$ & s) 0.5 & $0 \cdot 7$ & 0 & 0 & $0 \cdot 05$ & 0 & 0 & 0 & 0 & 0 & 0 & 0 \\
\hline A. gambiae & 0 & $5 \cdot 0$ & 0.3 & 0 & 0 & 0.7 & 0.2 & 0 & 0 & 0 & $0 \cdot 8$ & 0 & 0 & 0 & 0 \\
\hline A. funestus & 0 & $3 \cdot 2$ & $39 \cdot 5$ & $8 \cdot 5$ & 0 & $0 \cdot 2$ & 0 & 0 & 0 & 0 & 0 & 0 & 0 & 0 & 0 \\
\hline \multicolumn{16}{|c|}{ Treated huts at foot of escarpment (8-24 huts) } \\
\hline A. funestus & 2 & 24 & 75 & 28 & 2 & $0 \cdot 1$ & 0 & 0 & 0 & 0 & 0 & 0.3 & 0 & 0 & 0 \\
\hline
\end{tabular}

World War, and the development of roads and agriculture, have increased concurrently. On the Pare Mountains, roads are relatively undeveloped, and motor transport is, and was, virtually absent in this area. It is probably the strong winds, blowing up from the Mkomazi valley, that are chiefly responsible for carrying the mosquitoes into the mountains. Mosquito densities in huts suggest that some transmission was occurring in a few villages on the upper slopes of the Pare Mountains before huts in the plains were treated with dieldrin, although little or none occurred above the escarpment. Residual spraying in the plains greatly reduced anopheline infestation in huts on the mountains, and has therefore indirectly protected the inhabitants from the risk of malaria infection.

I am indebted to Mr. J. D. Phipps for his help during the three years of observations, and to Dr. D. Bagster Wilson for valuable criticism.

East Africa Institute of Malaria

A. Smith and Vector Borne Diseases,

Amani, Tanganyika.

Nov. 3.

${ }^{2}$ Draper, C. C., and Smith, A., Trans. Roy. Soc. Trop. Med. Hyg., 51,

${ }^{2}$ Garnham, P. C. C., J. Nat. Mal. Soe., 7, 275 (1948).

\section{Paper Electrophoretic Separation of the Proteins of Some Leguminous Seeds}

THe plant materials examined during this work were acetone powders prepared from lentils (Lens esculenta, Moench), 'horse' beans (Vicia faba, L.), lupin seeds (Lupinus termis, Forsk) and fenugreek seeds (Trigonella foenum-graecum, L.). Each acetone powder was extracted separately with $0.1 \mathrm{~N}$ boraxphthalate buffer at $p \mathrm{H} 8 \cdot 0$, the proportion being $10 \mathrm{gm}$. of acetone powder to $60 \mathrm{ml}$. of buffer. Extracts obtained in this way were subjected to paper electrophoresis on Whatman No. 1 filter paper in a Shandon horizontal tank. Borax-phthalate buffer, which was prepared by mixing $0.1 N$ borax and $0.1 N$ potassium hydrogen phthalate $(p \mathrm{H} 8.0)$, was used. A potential of $150 \mathrm{~V}$. was applied for $12 \mathrm{hr}$. The protein bands were dyed with azocarmine $B$ solution according to Turba and Enenkel's method ${ }^{3}$.

Four coloured bands (designated $A-D$ ) appeared in the electrophoretic pattern of each of the seed extracts. It was possible, by the use of ammonium sulphate fractionation, to isolate each of the proteins $B, C$, and $D$ from the extract of lentil seed. Each of the protein fractions was re-precipitated 2-3 times and each of the final precipitates was dissolved in a small volume of borax-phthalate buffer and dialysed against the same buffer. These protein fractions were tested electrophoretically along with a sample of the original extract.
Protein fraction $D$ (precipitated in the range 45-54 per cent saturated ammonium sulphate) was orangered in colour and fluorescent in ultra-violet light. The absorption spectrum was read with a Hilger spectrophotometer and showed maxima at 360, 460 and $550 \mathrm{~m} \mu$ (Fig. 1), which indicates that this protein is a flavoprotein.

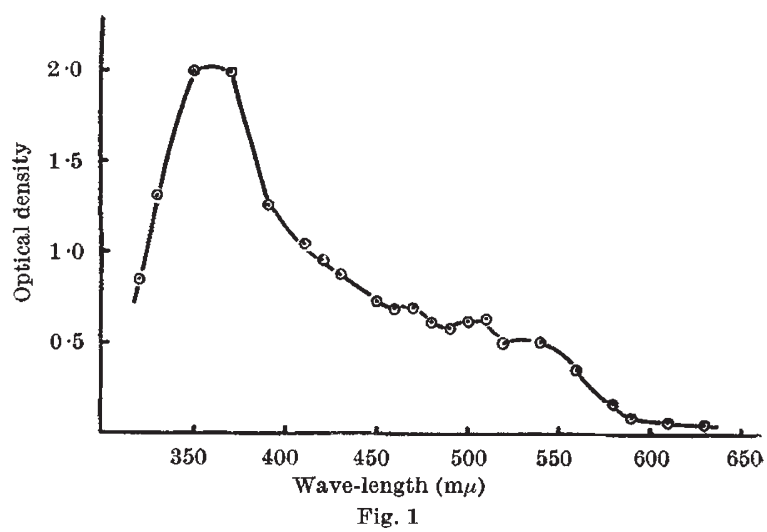

In order to determine the percentage of each of the protein constituents the filter paper was cut (in a direction perpendicular to the flow of the current) into strips $0.5 \mathrm{~cm}$. wide. Each of the small strips was eluted separately with $5 \mathrm{ml}$. 10 per cent ammonium hydroxide. The optical density of each extract was determined with a Unicam colorimeter using a filter (Ilford No. 303). By plotting optical density reading against the distance from the point of application of the protein extract to the strip an electrophoretic pattern was obtained. By means of a planimeter, the area under each peak was measured, and in this manner the percentage of the different proteins (in relation to the total proteins in the extract) was assessed. The results (Table 1) indicate that, although the extract of each of the four kinds of seeds under investigation contains the four fractions, the percentage of each of the proteins varies according to the type of seed.

Table 1. Amounts of VArious Proteins In SOME LEguminous SEedoS

\begin{tabular}{|l|r|r|r|r|}
\hline \multicolumn{1}{|c|}{ Seed } & \multicolumn{4}{|c|}{ Protein } \\
& $A$ & \multicolumn{1}{c|}{$\boldsymbol{B}$} & \multicolumn{1}{c|}{$\boldsymbol{C}$} \\
\hline Lupinus termis & $1 \cdot 89$ & $86 \cdot 55$ & $8 \cdot 79$ & $2 \cdot 75$ \\
Trigonella foenum-graecum & $5 \cdot 26$ & $84 \cdot 27$ & $5 \cdot 26$ & $5 \cdot 26$ \\
Vicia faba & $5 \cdot 11$ & $46 \cdot 51$ & $40 \cdot 23$ & $8 \cdot 13$ \\
Lens esculenta & $3 \cdot 91$ & $71 \cdot 02$ & $7 \cdot 57$ & $17 \cdot 49$ \\
\hline
\end{tabular}

Esam M. Moustafa

Department of Agricultural Chemistry, University of Khartoum, Sudan. Nov, 14.

${ }^{1}$ Turba, F., and Enenkel, H. J., Naturwiss., 37, 93 (1950). 